\title{
Anti-inflammatory effects of garenoxacin on IL-8 production and ERK1/2 activation induced by lipopolysaccharides in A549 and THP-1 cells
}

Shintaro Hara ${ }^{\dagger}$, Yuji Ishimatsu ${ }^{\dagger *}$, Hiroshi Mukae ${ }^{\S}$, Noriho Sakamoto ${ }^{\dagger}$, Tomoyuki

Kakugawa $^{\dagger}$, Hanako Fujita ${ }^{\dagger}$, Atsuko Hara ${ }^{\dagger}$, and Shigeru Kohno ${ }^{\dagger}$

${ }^{\dagger}$ Second Department of Internal Medicine, Nagasaki University School of Medicine,

1-7-1 Sakamoto, Nagasaki 852-8501, Japan and ${ }^{\S}$ Department of Respiratory Disease,

University of Occupational and Environmental Health, Japan, 1-1 Iseigaoka,

Yahata-nishi-ku, Kitakyusyu, Fukuoka 807-8555, Japan

*Corresponding author: Yuji Ishimatsu

Tel: +81-95-819-7273; Fax: +81-95-849-7285; E-mail address: yuji-i@nagasaki-u.ac.jp Second Department of Internal Medicine, Nagasaki University School of Medicine, 1-7-1 Sakamoto, Nagasaki 852-8501, Japan 


\begin{abstract}
The anti-inflammatory properties of macrolides have been applied to the treatment of inflammatory airway diseases. Although the anti-inflammatory properties of fluoroquinolones have been reported, no reports are available regarding a newly developed fluoroquinolone, garenoxacin (GRNX). To examine the immunomodulatory effect of GRNX, we examined the transcription and secretion of inflammatory cytokines by human airway epithelial cells and monocytes stimulated with lipopolysaccharide (LPS). A human lung epithelial cell line (A549) and a human monocyte cell line (THP-1) were stimulated with LPS and exposed to different concentrations of GRNX. The transcription and secretion of interleukin 8 (IL-8) in both A549 and THP-1 cells was measured by real-time PCR and an enzyme-linked immunosorbent assay, respectively. Treatment with GRNX significantly inhibited the transcription and secretion of IL-8 induced by LPS-stimulated cells through inhibitory ERK1/2 phosphorylation. GRNX has anti-inflammatory activity through its capacity to alter the secretion of IL-8 from A549 and THP-1 cell lines. Our findings suggest that GRNX is suitable for the treatment of LPS-induced respiratory infection and inflammatory airway diseases.
\end{abstract}

KEYWORDS: fluoroquinolones, macrolides, immunomodulatory effect, inflammatory cytokine, MAPK phosphorylation 


\section{Introduction}

Diffuse panbronchiolitis is a clinicopathological disease entity that is characterized by chronic inflammation localized in the respiratory bronchioles (Homma et al., 1983). Since the effectiveness of low-dose, long-term erythromycin treatment was established, diffuse panbronchiolitis has become easy to control and is now curable (Kadota et al., 1993). After the discovery of this treatment, a number of macrolides have been found to have significant immunomodulatory properties beyond their antibacterial activities. Inflammatory reactions, phagocytosis, natural cytotoxicity, cytokine production, antibody responses and cellular immunity are defensive mechanisms that might be modulated by therapeutic doses of other antimicrobial agents as well as macrolides (Labro, 2000; Williams, 2001).

Fluoroquinolones are synthetic, broad-spectrum antimicrobial agents that are commonly used to treat a variety of infections, including systemic infections in immune-compromised patients (Hooper and Wolfson, 1991). In addition to their antimicrobial properties, certain quinolones have significant immunomodulatory activities in vitro and in vivo (Dalhoff, 2005). A newly developed fluoroquinolone, garenoxacin mesilate hydrate (GRNX), has a low mutant prevention concentration (the concentration that prohibits the growth of mutants from a susceptible population of more than $10^{10}$ cells) and a narrow mutant selection window (defined as the range between the minimum inhibitory concentration and the mutant prevention concentration, provides a means for defining the ability of an antibiotic to prevent the emergence of mutants) and is useful for minimizing the selection of quinolone-resistant mutants of pneumococcal strains (Yamamoto et al., 2009). However, the immunomodulatory properties of GRNX in human lung cells have not previously been examined.

To confirm that GRNX has anti-inflammatory properties, we examined the 
transcription and production of IL-8 in A549 and THP-1 cells. In addition, we also examined the phosphorylation of ERK1/2 to clarify the immunomodulatory mechanism. 


\section{Materials and Methods}

\subsection{Reagents}

Clarithromycin (CAM) and GRNX were provided by Taisho-Toyama Pharmaceutical Co., Ltd., (Tokyo, Japan). Telithromycin (TEL) was provided by Sanofi-Aventis (Paris, France). Aminobenzyl penicillin (ABPC) was provided by Meiji Seika Pharma, Ltd., (Tokyo, Japan). Lipopolysaccharide (LPS; Pseudomonas aeruginosa serotype 10) was purchased from Sigma-Aldrich (St. Louis, MO, USA).

\subsection{Cell culture}

The human alveolar epithelial cell line A549 was purchased from the American Type Culture Collection (ATCC; Manassas, VA, USA) and grown as monolayers in tissue culture flasks (BD Falcon ${ }^{\mathrm{TM}}$; Franklin Lakes, NJ, USA) at $37^{\circ} \mathrm{C}$ in a $5 \%$ $\mathrm{CO}_{2}$-humidified atmosphere. The cells were maintained in Dulbecco's modified minimal essential medium (DMEM; Invitrogen, Carlsbad, CA, USA) supplemented with $10 \%$ heat-inactivated fetal bovine serum (FBS; Invitrogen). The cells were passaged weekly after exposure to $0.25 \%(\mathrm{w} / \mathrm{v})$ trypsin. Subconfluent A549 monolayers $\left(5.0 \times 10^{5}\right.$ cells $)$ were grown in 60 -mm dishes in DMEM without FBS for $24 \mathrm{~h}$ before starting experiments. As a negative control, the A549 cells were incubated with DMEM alone (without FBS). The human monocytic cell line THP-1 (ATCC TIB 202) was purchased from ATCC and maintained in RPMI 1640 medium (Invitrogen) supplemented with 10\% heat-inactivated FBS and $10 \mathrm{mM}$ 6-melcaptoethanol (Wako Pure Chemical Industries, Ltd., Osaka, Japan) at $37^{\circ} \mathrm{C}$ in a $5 \% \mathrm{CO}_{2}$-humidified atmosphere. Assays with THP-1 cells were performed at a density of $10^{6}$ cells $/ \mathrm{ml}$ in 6-well plates (Corning Incorporated, Corning, NY, USA). In the subsequent IL-8 production studies, THP-1 cells were stimulated with LPS while cultured in RPMI 1640 
with $2 \%$ heat-inactivated FBS.

\subsection{Real-Time PCR}

The IL-8 mRNA expression was measured by real-time PCR according to a procedure described previously (Amenomori et al., 2010; Hara et al., 2008). To determine the appropriate concentration of LPS, subconfluent A549 cells grown in 60 -mm cell culture dishes $\left(5.0 \times 10^{5} / \mathrm{dish}\right)$ and THP- 1 cells $\left(10^{6}\right.$ cells $\left./ \mathrm{ml}\right)$ in 6 -well plates were incubated for $3 \mathrm{~h}$ with medium alone (control) or $0.1,1,10$, or $100 \mathrm{ng} / \mathrm{ml}$ of LPS. After the appropriate concentration of LPS was determined from the preliminary experiments, cells were incubated for $3 \mathrm{~h}$ with medium alone (control) or LPS ( $1 \mathrm{ng} / \mathrm{ml})$ in the absence or presence of antibiotics (1.0 to $10 \mu \mathrm{g} / \mathrm{ml}$ of CAM, TEL, GRNX, or ABPC). Total RNA was isolated from cultured A549 cells and THP-1 cells using an RNeasy Plus Mini kit (Qiagen, Hilden, Germany) according to the manufacturer's recommendations. A volume of pooled RNA $(2 \mu \mathrm{l})$ was reverse-transcribed in a total reaction volume of $21 \mu \mathrm{l}$ containing $0.5 \mu \mathrm{g}$ random hexamer primer, 20 units RNasin ribonuclease inhibitor, and SuperScript III First-Strand Synthesis System (Invitrogen), according to the supplier's instructions. The resulting cDNA was subjected to quantitative real-time polymerase chain reaction (QRT-PCR). The QRT-PCR amplification was performed with TaqMan Gene Expression Assays for the IL-8 gene and human beta-actin as an endogenous control (Applied Biosystems, Foster City, CA, USA) in combination with the TaqMan Universal PCR Master Mix (Applied Biosystems). Cycle-to-cycle fluorescence emission readings were monitored and analyzed by the ABI PRISM 7700 Sequence Detection System (Applied Biosystems). Quantitation of IL-8 mRNA expression was calculated using the comparative $\mathrm{C}_{\mathrm{T}}$ method. 


\subsection{Enzyme-linked immunosorbent assay (ELISA)}

The IL-8 protein production was measured by ELISA according to a procedure described previously (Amenomori et al., 2010; Hara et al., 2008). To determine the appropriate concentration of LPS, subconfluent A549 cells in 60-mm cell culture dishes $\left(5.0 \times 10^{5} / \mathrm{dish}\right)$ and THP-1 cells in 6 -well plates $\left(10^{6}\right.$ cells $\left./ \mathrm{ml}\right)$ were incubated for $24 \mathrm{~h}$ (A549 cells) or $9 \mathrm{~h}$ (THP-1 cells) with medium alone (control) or 1, 10, or $100 \mathrm{ng} / \mathrm{ml}$ of LPS. After the appropriate concentrations of LPS were determined from the preliminary experiments, cells were incubated for 24 h (A549 cells) or 9 h (THP-1 cells) with medium alone (control) or LPS (10 ng/ml for A549 cells or $1 \mathrm{ng} / \mathrm{ml}$ for THP-1 cells) in the absence or presence of antibiotics (1.0 to $10 \mu \mathrm{g} / \mathrm{ml}$ of CAM, TEL, GRNX, or ABPC). Cell-free supernatants were recovered by centrifugation and stored at $-80^{\circ} \mathrm{C}$ until they were assayed. IL-8 levels were measured using a Quantikine human CXCL8/IL-8 ELISA kit according to the supplier's instructions (R\&D Systems Inc., Minneapolis, MN, USA).

\subsection{Western blotting}

ERK1/2 phosphorylation was measured by Western blotting according to a procedure described previously (Ishimoto et al., 2009). To determine the appropriate concentration of LPS for this assay, A549 cells and THP-1 cells were preincubated in serum-free medium at $37^{\circ} \mathrm{C}$ for $3 \mathrm{~h}$ prior to the addition of $10 \mathrm{ng} / \mathrm{ml}, 100 \mathrm{ng} / \mathrm{ml}, 1$ $\mu \mathrm{g} / \mathrm{ml}$, or $10 \mu \mathrm{g} / \mathrm{ml}$ of LPS (for A549 cells) or 1, 10, or $100 \mathrm{ng} / \mathrm{ml}$ of LPS (for THP-1 cells). Cells were incubated with LPS for $5 \mathrm{~min}$. To determine the appropriate incubation time, cells were preincubated in serum-free medium for $3 \mathrm{~h}$ prior to the addition of $10 \mu \mathrm{g} / \mathrm{ml}$ of LPS for A549 cells or $100 \mathrm{ng} / \mathrm{ml}$ of LPS for THP-1 cells. Cells 
were incubated with LPS for 5, 15, 30 or 60 min. After the LPS concentration and exposure time were determined from the preliminary assays, A549 cells and THP-1 cells were preincubated in serum-free medium at $37^{\circ} \mathrm{C}$ for $3 \mathrm{~h}$ in the absence or presence of $10 \mu \mathrm{g} / \mathrm{ml}$ of CAM or GRNX prior to the addition of $10 \mu \mathrm{g} / \mathrm{ml}$ LPS for A549 cells or $100 \mathrm{ng} / \mathrm{ml}$ of LPS for TPH-1 cells. For Western blotting analysis of ERK1/2, cells were incubated with LPS for 15 min (for A549 cells) or 5 min (for THP-1 cells). Then, the cells were washed twice with cold PBS and suspended in $600 \mu 1$ (for A549 cells) or $40 \mu 1$ (for THP-1 cells) of cell lysis buffer (Cell Signaling Technology, Inc., Danvers, MA, USA) that contained a 1:25 dilution of protease inhibitor cocktail (Nacalai Tesque Inc., Kyoto, Japan). After being kept on ice for $15 \mathrm{~min}$, the lysates were subjected to centrifugation $(20,000 \times \mathrm{g})$ at $4^{\circ} \mathrm{C}$ for $15 \mathrm{~min}$ to obtain a cytosolic fraction. The protein concentration was determined by a Bradford assay (Bio-Rad, Munich, Germany) before storage at $-70^{\circ} \mathrm{C}$. An aliquot of the cytosol fraction containing $20 \mu \mathrm{g}$ of protein was resolved by $10 \%$ SDS-PAGE. After electrophoresis and electrophoretic transfer of proteins to Immun-Blot PVDF membranes (Bio-Rad), the membranes were blocked with 5\% non-fat milk in Tris-buffered saline ( $\mathrm{pH} 7.4$ ) containing $0.1 \%$ Tween (TBST) for $1 \mathrm{~h}$. Membranes were incubated at room temperature with a 1:1000 dilution of rabbit anti-human ERK 1/2 or phosphorylated ERK 1/2 antibodies (Cell Signaling Technology Inc.) overnight at $4^{\circ} \mathrm{C}$. Subsequently, the membranes were incubated with a secondary antibody, horseradish peroxidase-linked anti-rabbit IgG (GE Healthcare UK Ltd., Buckinghamshire, UK), for $1 \mathrm{~h}$ at room temperature. The blots were washed three times in TBST and incubated in enhanced chemiluminescence reagent (Amersham ECL Plus Western Blot detecting system; GE Healthcare). The specific bands were photographed by FluorChem (Cell Biosciences, Inc., Santa Clara, CA, USA). Relative density values of ERK1/2 were determined by densitometric analysis (NIH Image J 
software, version 1.14o, NIH, Bethesda, MD, USA).

\subsection{Statistical analysis}

Values are expressed as mean \pm standard error of mean (S.E.M.) for continuous parameters. All statistical analyses were performed with StatMate III for Macintosh (version 3.14, ATMS Co., Ltd., Tokyo, Japan). Results were analyzed by the Student's t-test for comparison between two groups and by the non-parametric equivalents of analysis of variance (ANOVA) with Newman-Keuls's multiple comparison test using either vehicle control or LPS treatment as references. Significance was assumed at $\mathrm{P}<$ 0.05 . 


\section{Results}

3.1 Effect of CAM, TEL, GRNX, and ABPC on IL-8 mRNA expression in A549 and THP-1 cells stimulated with LPS

To determine the effect of LPS concentration on IL-8 mRNA expression, both cell lines were incubated with various concentrations of LPS for $3 \mathrm{~h}$. The optimal stimulation time was confirmed according to a procedure described previously (Amenomori et al., 2010; Hara et al., 2008). There was a dose-dependent increase in IL-8 mRNA expression by LPS stimulation ( 0.1 to $100 \mathrm{ng} / \mathrm{ml})$, with significant increases in expression occurring at LPS concentrations greater than $1 \mathrm{ng} / \mathrm{ml}$ (Fig. 1A, 1B). Therefore, further experiments for examining the mRNA expression were performed with $1 \mathrm{ng} / \mathrm{ml}$ of LPS.

To determine if GRNX can inhibit IL-8 mRNA expression induced by LPS in A549 cells and THP-1 cells, A549 cells were incubated with medium alone (control) or $1 \mathrm{ng} / \mathrm{ml}$ of LPS in the absence or presence of various antibiotics (CAM, TEL, GRNX, and ABPC). IL-8 mRNA expression increased in LPS-activated A549 cells (1.4 fold; Fig. 1C) and THP-1 cells (19 fold; Fig. 1D) at $3 \mathrm{~h}$ after stimulation. The addition of CAM, TEL, and GRNX at concentrations of 1 or $10 \mu \mathrm{g} / \mathrm{ml}$ significantly inhibited the mRNA expression of IL-8. ABPC, however, did not inhibit mRNA expression. The 1 $\mu \mathrm{g} / \mathrm{ml}$ concentration of all drugs (except $\mathrm{ABPC}$ ) provided equivalent inhibition as the 10 $\mu \mathrm{g} / \mathrm{ml}$ concentration (no significance difference between the two concentrations). There was no significant difference in the level of inhibition mediated by CAM, TEL, and GRNX.

3.2 Effect of CAM, TEL, GRNX, and ABPC on IL-8 protein production by A549 and THP-1 cells stimulated with LPS 
To determine the effect of LPS concentration on IL-8 protein production, cells were incubated with various concentrations of LPS for $24 \mathrm{~h}$ (for A549 cells) and for $9 \mathrm{~h}$ (for THP-1 cells). Stimulation time for A549 cells was confirmed according to a procedure described previously (Amenomori et al., 2010; Hara et al., 2008). We found that LPS (concentrations ranging from 1 to $100 \mathrm{ng} / \mathrm{ml}$ ) activated production of IL-8 in A549 cells in a dose-dependent manner. In A549 cells, LPS at concentrations greater than $10 \mathrm{ng} / \mathrm{ml}$ caused a statistically significant increase in IL- 8 protein production at 24 h (Fig. 2A). An LPS concentration of $10 \mathrm{ng} / \mathrm{ml}$ was used for further ELISA experiments with A549 cells. In THP-1 cells, LPS concentrations ranging from 0.1 to $100 \mathrm{ng} / \mathrm{ml}$ and stimulation times ranging from 6 to $24 \mathrm{~h}$ exhibited a stimulatory effect in which IL-8 production was increased in a dose- and time-dependent manner (Fig. 2B). Concentrations of LPS greater than $1 \mathrm{ng} / \mathrm{ml}$ with stimulation times greater than $9 \mathrm{~h}$ caused statistically significant increases in IL-8 protein production (time-dependent experiments are not shown). Therefore, $1 \mathrm{ng} / \mathrm{ml}$ of LPS with a 9-h stimulatory time was used for further ELISA experiments with THP-1 cells.

In Fig. 2C, IL-8 protein production increased in LPS-activated A549 cells by 7.2 fold. The addition of CAM, TEL, and GRNX at concentrations of 1 or $10 \mu \mathrm{g} / \mathrm{ml}$ significantly inhibited the IL-8 protein production. ABPC did not inhibit IL-8 production. The $1 \mu \mathrm{g} / \mathrm{ml}$ and $10 \mu \mathrm{g} / \mathrm{ml}$ concentrations of all drugs (except ABPC) yielded equivalent levels of inhibition. No statistically significant differences were seen between the two concentrations or among the three drugs (CAM, TEL, and GRNX).

In Fig. 2D, IL-8 protein production increased in LPS-activated THP-1 cells by 21.2 fold. By the multiple comparison test, only GRNX at $10 \mu \mathrm{g} / \mathrm{ml}$ significantly inhibited the production of IL-8. CAM, TEL and ABPC did not inhibit IL-8 production. 


\subsection{Effect of CAM and GRNX on ERK1/2 phosphorylation in LPS-stimulated A549 and}

THP-1 cells

To determine the effect of LPS concentration and stimulation time on ERK1/2 phosphorylation, cells were incubated with various concentrations of LPS for various amounts of time, as described previously (Ishimoto et al., 2009). For concentration determination, cells were stimulated by various concentration of LPS (10 ng/ml, 100 $\mathrm{ng} / \mathrm{ml}, 1 \mu \mathrm{g} / \mathrm{ml}$, and $10 \mu \mathrm{g} / \mathrm{ml}$ for A549 cells; 1,10 , and $100 \mathrm{ng} / \mathrm{ml}$ for THP-1 cells) for 5 min after 3 h preincubation with serum-free medium. LPS induced ERK1/2 activity in a dose-dependent manner (Fig. 3A and 3B). An LPS concentration of $10 \mu \mathrm{g} / \mathrm{ml}$ for A549 cells and $100 \mathrm{ng} / \mathrm{ml}$ for THP-1 cells was used for further ERK1/2 activity experiments. For time determination, cells were stimulated by LPS for 5-60 min. LPS induced a transient increase in ERK 1/2 activity, which peaked at 15 min in A549 cells (Fig. 3C) or 5 min in THP-1 cells (Fig. 3D) and decreased at $60 \mathrm{~min}$. A stimulation time of $15 \mathrm{~min}$ for A549 cells or 5 min for THP-1 cells was used for further Western blotting experiments. Our preliminary experiments indicated that both cell lines required a much higher LPS concentration to evaluate the phosphorylation of ERK1/2 with Western blotting than to evaluate IL-8 mRNA expression and protein production.

The results of LPS-induced ERK1/2 activation and the effects of CAM and GRNX on the activation are presented in Fig. 3E and 3F. The data in Fig. 3E show that the addition of CAM or GRNX at a concentration of $10 \mu \mathrm{g} / \mathrm{ml}$ inhibited LPS-induced ERK $1 / 2$ phosphorylation in A549 cells by $31.8 \%( \pm 9.5 \%)(\mathrm{P}<0.05)$ or $40.4 \%( \pm$ 13.7\%) $(\mathrm{P}<0.05)$, respectively. As shown in Fig. 3F, the addition of CAM or GRNX at a concentration of $10 \mathrm{ng} / \mathrm{ml}$ inhibited LPS-induced ERK 1/2 phosphorylation in THP-1 cells by $35.5 \%( \pm 15.8 \%)(\mathrm{P}<0.05)$ or $43.8 \%( \pm 7.7 \%)(\mathrm{P}<0.05)$, respectively. 


\section{Discussion}

We demonstrated for the first time that GRNX significantly attenuated LPS-induced IL-8 transcription and production through the negative regulation of the ERK1/2 pathway both in the human airway epithelial cell line A549 and the monocyte cell line THP-1.

The major finding of the present study is that GRNX significantly inhibited LPS-induced IL-8 expression both in airway epithelial cells and monocytes. LPS is a major component of the outer membrane of Gram-negative bacteria including P. aeruginosa, which is a major pathogen in chronic respiratory tract infection. LPS induces airway epithelial cells to produce IL-8, a potent chemokine that is important in airway neutrophilic inflammation(Baggiolini et al., 1989). Although IL-8 plays a key role in the host defense mechanism through its effect on neutrophil activation, a continued presence of IL-8 in airway lining fluid and circulation in response to an inflammatory condition may lead to a variable degree of tissue damage, including diffuse panbronchiolitis, acute respiratory distress syndrome, and sepsis (Bellomo, 1992; Mukae et al., 1995; Standiford et al., 1990) in which the levels of IL-8 were decreased by successful therapy (Kadota et al., 1993; Mattoli et al., 1991). The greater release of pro-inflammatory cytokines in these patients may indicate that a dysregulation of pro- and anti-inflammatory responses contributes to the increased severity. In addition, the epithelial lining of the respiratory airways is the first tissue to encounter pathogens and their products; therefore, it is a critical tissue in the innate immune system and the front line of the host defense against invading microorganisms (Zhang et al., 2000). Monocytes also have a pivotal role in the early cytokine response to a number of pathogens and/or their products, which serve as major mediators of the acute inflammatory response (Baumann and Gauldie, 1994). Therefore, our results that 
GRNX inhibited IL-8 production both in LPS-stimulated A549 and THP-1 cells should have some value in the treatment of respiratory infection.

A number of studies have demonstrated the immunomodulatory properties of macrolides (Khan et al., 1999; Morikawa et al., 2002). In addition, anti-inflammatory effects of quinolones, such as moxifloxacin (Araujo et al., 2002), gatifloxacin (Takeyama et al., 2007), ciprofloxacin (Kaji et al., 2008), and besifloxacin (Zhang and Ward, 2008), have also been reported. In Table 1, we list several reports about inhibitory effects of antibiotic on IL-8 production induced by stimuli in vitro. A few reports have compared the anti-inflammatory effects of fluoroquinolones and macrolides. Brau et al. reported that moxifloxacin but not ciprofloxacin selectively inhibited inflammatory cytokines in a cystic fibrosis epithelial cell line (Blau et al., 2007). In the present study, we demonstrated for the first time that GRNX at a concentration of 1 or $10 \mu \mathrm{g} / \mathrm{ml}$, which reflects the peak blood levels of GRNX in vivo, inhibited IL-8 mRNA expression and production in A549 cells as well as CAM and TEL. In addition, our study demonstrated that GRNX, CAM and TEL inhibited IL-8 mRNA expression in THP-1 cells, whereas only GRNX, but not CAM or TEL, inhibited IL-8 production. While the inhibition of IL-8 production by CAM and TEL in monocytes has been previously reported (Kikuchi et al., 2002; Leiva et al., 2008; Lotter et al., 2006), our results show that the effects on IL-8 production might be associated with the cell type or the treatment time. As shown in Table 1, the cell type, stimulus, and simulation time varied in similar reports.

We demonstrated that GRNX inhibited LPS-activated phosphorylation of ERK 1/2. Among a variety of signal transduction molecules, MAPK is one of the signaling molecules required for LPS-induced IL 8 production in A549 and THP-1 cells (Hoffmann et al., 2002; Liu et al., 2000; Scherle et al., 1998). MAPK can act 
independently on both the NF-kB and AP-1 transcription pathways of IL-8 production (Henry et al., 1998; Ishikawa et al., 1995; Standiford et al., 1990). This study indicates that inhibition of ERK1/2 phosphorylation could be one of the anti-inflammatory mechanisms of GRNX. This study has limitations in that we did not clarify whether GRNX affects other cell signalling pathways, as reported for other macrolides and fluoroquinolone, which down-regulate the expression of TLR-4 (Kaji et al., 2008), NF-kB or AP-1(Blau et al., 2007; Takeyama et al., 2007; Weiss et al., 2004). Further research is required.

Long-term macrolide therapy (LTMT) is effective in patients with chronic bronchial infections such as diffuse panbronchiolitis, cystic fibrosis and bronchiectasis. After LTMT became widely recognized, macrolides have been reported to have not only an antibacterial activity but also an immunomodulatory activity (as mentioned above). However, sometimes acute exacerbations occur during LTMT due to bacterial infections including Streptococcus pneumoniae. Most of the S. pneumoniae strains isolated from patients receiving LTMT are resistant to macrolides while remaining susceptible to quinolones (Kasahara et al., 2005; Maeda et al., 2001). Given such a background, our results, in which the novel quinolone GRNX with greater antibacterial activity for penicillin-resistant S. pneumoniae attenuates LPS-induced IL-8 transcription and production as well as macrolides, suggest that GRNX could have clinical value in the management of acute exacerbations of chronic respiratory tract infections to prevent the spread of infection and prolonged inflammation.

In conclusion, we have demonstrated that GRNX inhibits the LPS-stimulated production of IL- 8 mRNA and protein in both a lung epithelial cell line and a monocyte cell line. 


\section{Acknowledgments}

This work was supported in part by Grants-in-Aid for Scientific Research

[KAKENHI; grant number 20590927] (C), Health, Labour and Welfare Ministry, Japan.

The authors thank Dr. Mariko Mine (Division of Scientific Data Registry:

Biostatistics Section, Atomic Bomb Disease Institute, Nagasaki University Graduate

School of Biomedical Sciences) for her statistical advice and Mr. Atsushi Yokoyama

(Nagasaki University Hospital) for his excellent technical assistance. 


\section{References}

Amenomori, M., Mukae, H., Ishimatsu, Y., Sakamoto, N., Kakugawa, T., Hara, A., Hara, S., Fujita, H., Ishimoto, H., Hayashi, T., Kohno, S., 2010. Differential effects of human neutrophil peptide-1 on growth factor and interleukin-8 production by human lung fibroblasts and epithelial cells. Exp Lung Res 36, 411-419.

Andrews, J., Honeybourne, D., Jevons, G., Boyce, M., Wise, R., Bello, A., Gajjar, D., 2003. Concentrations of garenoxacin in plasma, bronchial mucosa, alveolar macrophages and epithelial lining fluid following a single oral $600 \mathrm{mg}$ dose in healthy adult subjects. J Antimicrob Chemother 51, 727-730.

Araujo, F.G., Slifer, T.L., Remington, J.S., 2002. Effect of moxifloxacin on secretion of cytokines by human monocytes stimulated with lipopolysaccharide. Clin Microbiol Infect 8, 26-30.

Baggiolini, M., Walz, A., Kunkel, S.L., 1989. Neutrophil-activating peptide-1/interleukin 8, a novel cytokine that activates neutrophils. J Clin Invest 84, 1045-1049.

Baumann, H., Gauldie, J., 1994. The acute phase response. Immunol Today 15, 74-80.

Bellomo, R., 1992. The cytokine network in the critically ill. Anaesth Intensive Care 20, 288-302.

Blau, H., Klein, K., Shalit, I., Halperin, D., Fabian, I., 2007. Moxifloxacin but not ciprofloxacin or azithromycin selectively inhibits IL-8, IL-6, ERK1/2, JNK, and NF-kappaB activation in a cystic fibrosis epithelial cell line. Am J Physiol Lung 
Cell Mol Physiol 292, L343-352.

Dalhoff, A., 2005. Immunomodulatory activities of fluoroquinolones. Infection 33

Suppl 2, 55-70.

Donnarumma, G., Paoletti, I., Buommino, E., Iovene, M.R., Tudisco, L., Cozza, V., Tufano, M.A., 2007. Anti-inflammatory effects of moxifloxacin and human beta-defensin 2 association in human lung epithelial cell line (A549) stimulated with lipopolysaccharide. Peptides 28, 2286-2292.

Edlund, C., Alvan, G., Barkholt, L., Vacheron, F., Nord, C.E., 2000.

Pharmacokinetics and comparative effects of telithromycin (HMR 3647) and clarithromycin on the oropharyngeal and intestinal microflora. J Antimicrob Chemother 46, 741-749.

Hara, S., Mukae, H., Sakamoto, N., Ishimoto, H., Amenomori, M., Fujita, H., Ishimatsu, Y., Yanagihara, K., Kohno, S., 2008. Plectasin has antibacterial activity and no affect on cell viability or IL-8 production. Biochem Biophys Res Commun 374, 709-713.

Henry, J.R., Rupert, K.C., Dodd, J.H., Turchi, I.J., Wadsworth, S.A., Cavender, D.E., Schafer, P.H., Siekierka, J.J., 1998. Potent inhibitors of the MAP kinase p38. Bioorg Med Chem Lett 8, 3335-3340.

Hoffmann, E., Dittrich-Breiholz, O., Holtmann, H., Kracht, M., 2002. Multiple control of interleukin-8 gene expression. J Leukoc Biol 72, 847-855.

Homma, H., Yamanaka, A., Tanimoto, S., Tamura, M., Chijimatsu, Y., Kira, S., Izumi, T., 1983. Diffuse panbronchiolitis. A disease of the transitional zone of the 
lung. Chest 83, 63-69.

Hooper, D.C., Wolfson, J.S., 1991. Fluoroquinolone antimicrobial agents. N Engl J Med 324, 384-394.

Ishikawa, Y., Mukaida, N., Kuno, K., Rice, N., Okamoto, S., Matsushima, K., 1995. Establishment of lipopolysaccharide-dependent nuclear factor kappa B activation in a cell-free system. J Biol Chem 270, 4158-4164.

Ishimoto, H., Mukae, H., Sakamoto, N., Amenomori, M., Kitazaki, T., Imamura, Y., Fujita, H., Ishii, H., Nakayama, S., Yanagihara, K., Kohno, S., 2009. Different effects of telithromycin on MUC5AC production induced by human neutrophil peptide-1 or lipopolysaccharide in NCI-H292 cells compared with azithromycin and clarithromycin. J Antimicrob Chemother 63, 109-114.

Jang, Y.J., Kwon, H.J., Lee, B.J., 2006. Effect of clarithromycin on rhinovirus-16 infection in A549 cells. Eur Respir J 27, 12-19.

Kadota, J., Sakito, O., Kohno, S., Sawa, H., Mukae, H., Oda, H., Kawakami, K., Fukushima, K., Hiratani, K., Hara, K., 1993. A mechanism of erythromycin treatment in patients with diffuse panbronchiolitis. Am Rev Respir Dis 147, 153-159.

Kaji, M., Tanaka, J., Sugita, J., Kato, N., Ibata, M., Shono, Y., Ohta, S., Kondo, T., Asaka, M., Imamura, M., 2008. Ciprofloxacin inhibits lipopolysaccharide-induced toll-like receptor-4 and 8 expression on human monocytes derived from adult and cord blood. Ann Hematol 87, 229-231.

Kasahara, K., Kita, E., Maeda, K., Uno, K., Konishi, M., Yoshimoto, E., 
Murakawa, K., Mikasa, K., Kimura, H., 2005. Macrolide resistance of Streptococcus pneumoniae isolated during long-term macrolide therapy: difference between erythromycin and clarithromycin. J Infect Chemother 11, 112-114.

Khan, A.A., Slifer, T.R., Araujo, F.G., Remington, J.S., 1999. Effect of clarithromycin and azithromycin on production of cytokines by human monocytes. Int J Antimicrob Agents 11, 121-132.

Kikuchi, T., Hagiwara, K., Honda, Y., Gomi, K., Kobayashi, T., Takahashi, H., Tokue, Y., Watanabe, A., Nukiwa, T., 2002. Clarithromycin suppresses lipopolysaccharide-induced interleukin-8 production by human monocytes through AP-1 and NF-kappa B transcription factors. J Antimicrob Chemother 49, 745-755.

Kohno, Y., Yoshida, H., Suwa, T., Suga, T., 1989. Comparative pharmacokinetics of clarithromycin (TE-031), a new macrolide antibiotic, and erythromycin in rats. Antimicrob Agents Chemother 33, 751-756.

Labro, M.T., 2000. Interference of antibacterial agents with phagocyte functions: immunomodulation or "immuno-fairy tales"? Clin Microbiol Rev 13, 615-650. Leiva, M., Ruiz-Bravo, A., Jimenez-Valera, M., 2008. Effects of telithromycin in in vitro and in vivo models of lipopolysaccharide-induced airway inflammation. Chest 134, 20-29.

Liu, R., O'Connell, M., Johnson, K., Pritzker, K., Mackman, N., Terkeltaub, R., 2000. Extracellular signal-regulated kinase 1/extracellular signal-regulated kinase 
2 mitogen-activated protein kinase signaling and activation of activator protein 1 and nuclear factor kappaB transcription factors play central roles in interleukin-8 expression stimulated by monosodium urate monohydrate and calcium pyrophosphate crystals in monocytic cells. Arthritis Rheum 43, 1145-1155. Lotter, K., Hocherl, K., Bucher, M., Kees, F., 2006. In vivo efficacy of telithromycin on cytokine and nitric oxide formation in lipopolysaccharide-induced acute systemic inflammation in mice. J Antimicrob Chemother 58, 615-621.

Maeda, K., Mikasa, K., Konishi, M., Takahashi, K., Majima, T., Murakawa, K., Yoshimoto, E., Sakamoto, M., Narita, N., Sano, R., Masutani, T., Nakamura, S., 2001. [Acute exacerbations due to Streptococcus pneumoniae in chronic lower respiratory tract infections during long-term macrolide therapy]. Kansenshogaku Zasshi 75, 846-850.

Matsuoka, N., Eguchi, K., Kawakami, A., Tsuboi, M., Kawabe, Y., Aoyagi, T., Nagataki, S., 1996. Inhibitory effect of clarithromycin on costimulatory molecule expression and cytokine production by synovial fibroblast-like cells. Clin Exp Immunol 104, 501-508.

Mattoli, S., Mattoso, V.L., Soloperto, M., Allegra, L., Fasoli, A., 1991. Cellular and biochemical characteristics of bronchoalveolar lavage fluid in symptomatic nonallergic asthma. J Allergy Clin Immunol 87, 794-802.

Morikawa, K., Zhang, J., Nonaka, M., Morikawa, S., 2002. Modulatory effect of macrolide antibiotics on the Th1- and Th2-type cytokine production. Int $\mathbf{J}$ Antimicrob Agents 19, 53-59. 
Mukae, H., Kadota, J., Kohno, S., Kusano, S., Morikawa, T., Matsukura, S., Hara, K., 1995. Increase in activated CD8+ cells in bronchoalveolar lavage fluid in patients with diffuse panbronchiolitis. Am J Respir Crit Care Med 152, 613-618.

Na, Y.J., Jeon, Y.J., Suh, J.H., Kang, J.S., Yang, K.H., Kim, H.M., 2001.

Suppression of IL-8 gene expression by radicicol is mediated through the inhibition of ERK1/2 and p38 signaling and negative regulation of NF-kappaB and AP-1. Int Immunopharmacol 1, 1877-1887.

Nakagawa, S., Kojio, S., Taneike, I., Iwakura, N., Tamura, Y., Kushiya, K., Gondaira, F., Yamamoto, T., 2003. Inhibitory action of telithromycin against Shiga toxin and endotoxin. Biochem Biophys Res Commun 310, 1194-1199. MEIJI SEIKA Pharma, 2009. VICCILLIN® CAPSULES 250mg (product document).

Scherle, P.A., Jones, E.A., Favata, M.F., Daulerio, A.J., Covington, M.B., Nurnberg, S.A., Magolda, R.L., Trzaskos, J.M., 1998. Inhibition of MAP kinase kinase prevents cytokine and prostaglandin E2 production in lipopolysaccharide-stimulated monocytes. J Immunol 161, 5681-5686.

Shalit, I., Halperin, D., Haite, D., Levitov, A., Romano, J., Osherov, N., Fabian, I., 2006. Anti-inflammatory effects of moxifloxacin on IL-8, IL-1beta and TNF-alpha secretion and NFkappaB and MAP-kinase activation in human monocytes stimulated with Aspergillus fumigatus. J Antimicrob Chemother 57, 230-235. Shinkai, M., Lopez-Boado, Y.S., Rubin, B.K., 2007. Clarithromycin has an immunomodulatory effect on ERK-mediated inflammation induced by 
Pseudomonas aeruginosa flagellin. J Antimicrob Chemother 59, 1096-1101.

Standiford, T.J., Kunkel, S.L., Basha, M.A., Chensue, S.W., Lynch, J.P., 3rd, Toews, G.B., Westwick, J., Strieter, R.M., 1990. Interleukin-8 gene expression by a pulmonary epithelial cell line. A model for cytokine networks in the lung. $\mathrm{J}$ Clin Invest 86, 1945-1953.

Takeyama, K., Mitsuzawa, H., Nishitani, C., Shimizu, T., Sano, H., Kunishima, Y., Takahashi, S., Hotta, H., Matsukawa, M., Shibata, K., Tsukamoto, T., Kuroki, Y., 2007. The 6-fluoro-8-methoxy quinolone gatifloxacin down-regulates interleukin-8 production in prostate cell line PC-3. Antimicrob Agents Chemother 51, 162-168. Takizawa, H., Desaki, M., Ohtoshi, T., Kawasaki, S., Kohyama, T., Sato, M., Tanaka, M., Kasama, T., Kobayashi, K., Nakajima, J., Ito, K., 1997. Erythromycin modulates IL-8 expression in normal and inflamed human bronchial epithelial cells. Am J Respir Crit Care Med 156, 266-271.

Weiss, T., Shalit, I., Blau, H., Werber, S., Halperin, D., Levitov, A., Fabian, I., 2004. Anti-inflammatory effects of moxifloxacin on activated human monocytic cells: inhibition of NF-kappaB and mitogen-activated protein kinase activation and of synthesis of proinflammatory cytokines. Antimicrob Agents Chemother 48, 1974-1982.

Williams, J.D., 2001. Non-antimicrobial activities of macrolides. Int J Antimicrob Agents 18 Suppl 1, S89-91.

Yamamoto, K., Yanagihara, K., Sugahara, K., Imamura, Y., Seki, M., Izumikawa, K., Kakeya, H., Yamamoto, Y., Hirakata, Y., Kamihira, S., Kohno, S., 2009. In vitro 
activity of garenoxacin against Streptococcus pneumoniae mutants with characterized resistance mechanisms. Antimicrob Agents Chemother 53, 3572-3575.

Zhang, J.Z., Ward, K.W., 2008. Besifloxacin, a novel fluoroquinolone antimicrobial agent, exhibits potent inhibition of pro-inflammatory cytokines in human THP-1 monocytes. J Antimicrob Chemother 61, 111-116.

Zhang, P., Summer, W.R., Bagby, G.J., Nelson, S., 2000. Innate immunity and pulmonary host defense. Immunol Rev 173, 39-51. 


\section{Figure legends}

(A)

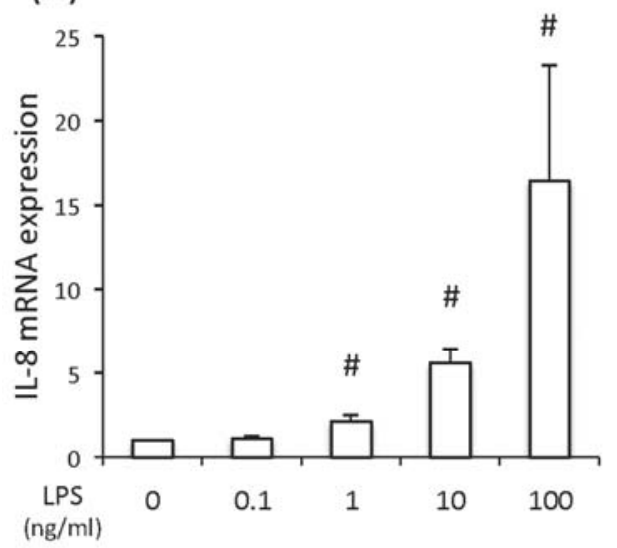

(B)

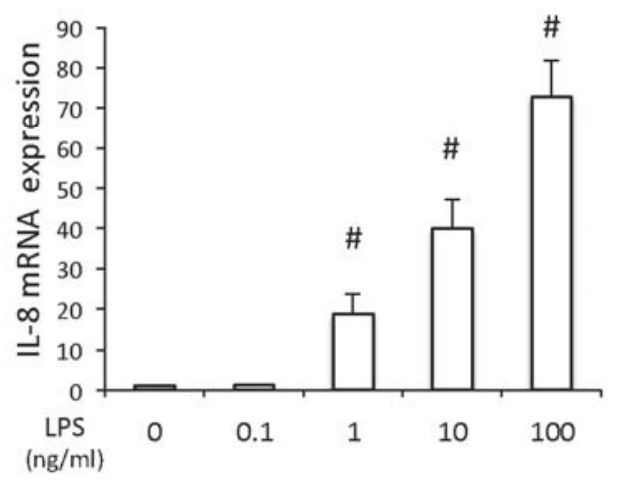

(C)

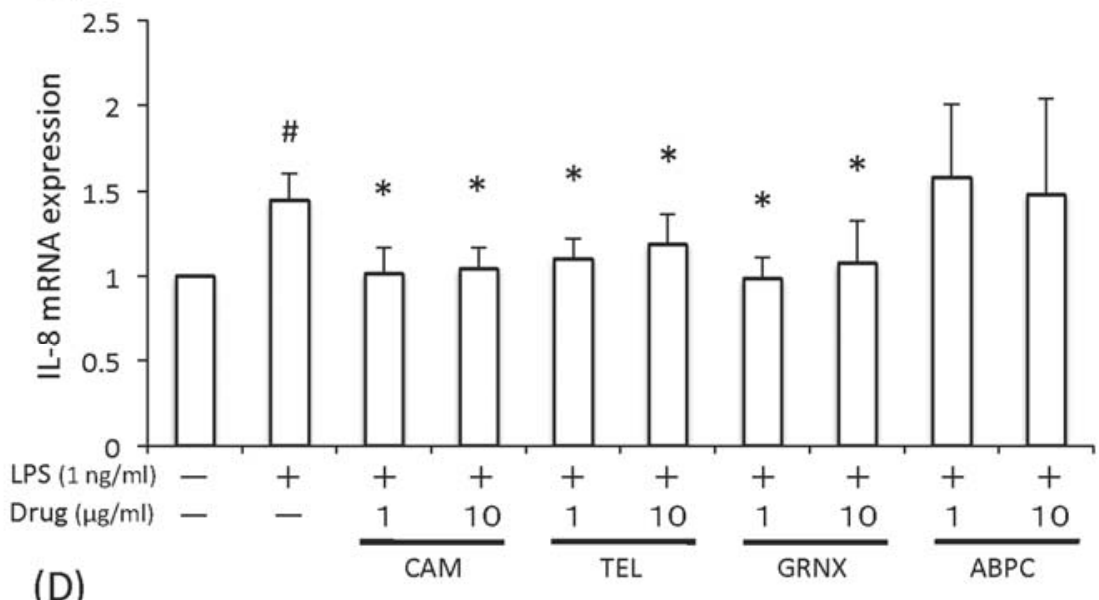

(D)

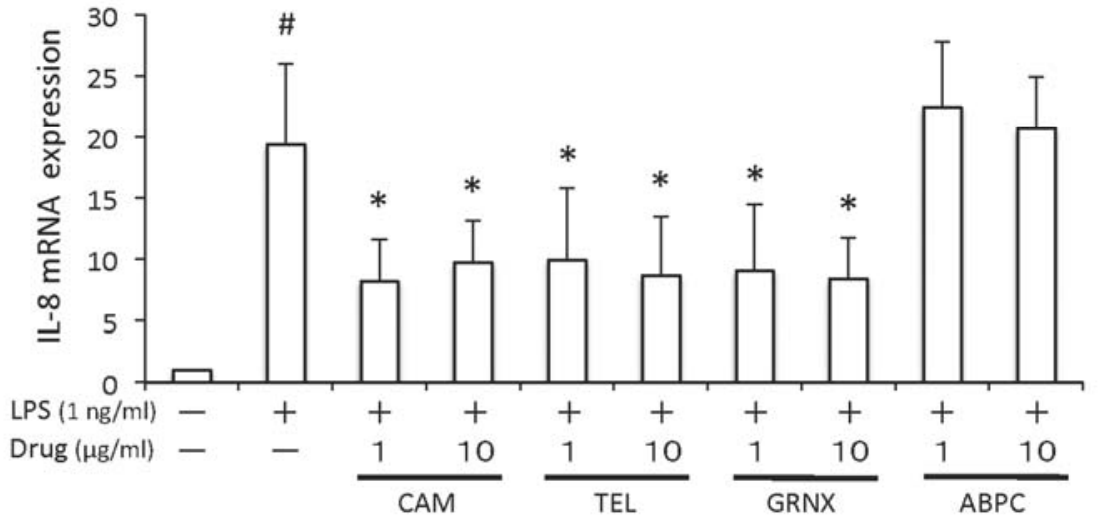

Fig. 1. Effects of clarithromycin (CAM), telithromycin (TEL), garenoxacin (GRNX) and ampicillin (ABPC) on the transcription of IL-8 mRNA

A and B: Concentration-dependent studies. A549 (A) and THP-1 cells (B) were incubated with the indicated concentration of LPS for $3 \mathrm{~h}$. C and D: A549 (C) and THP-1 cells (D) were incubated in medium alone (control) or LPS $(1 \mathrm{ng} / \mathrm{ml})$ in the presence or absence of CAM, TEL, GRNX and ABPC (1 or $10 \mu \mathrm{g} / \mathrm{ml})$. Every experiment was performed in duplicate, and the values represent means \pm S.E.M. of four independent experiments. \# denotes a statistically significant difference as compared with control $(\mathrm{P}<0.05)$, and * denotes a statistically significant difference as compared with LPS stimulation alone $(\mathrm{P}<0.05)$. 

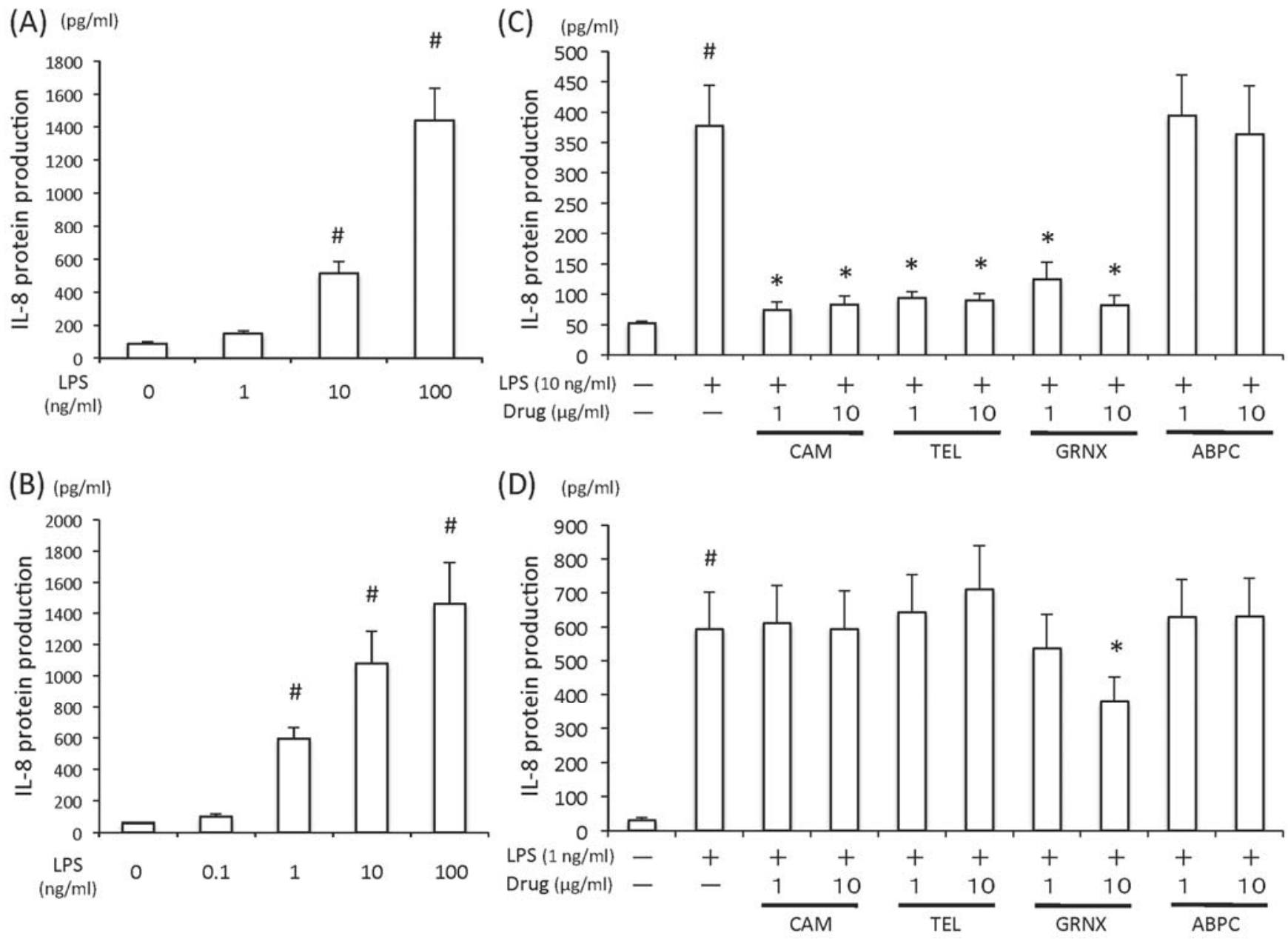

Fig. 2. Effects of clarithromycin (CAM), telithromycin (TEL), garenoxacin (GRNX) and ampicillin (ABPC) on the production of IL-8 protein

A and B: Concentration-dependent studies. Cells were incubated with the indicated concentration of LPS for $24 \mathrm{~h}$ (A549 cells; (A)) and for $9 \mathrm{~h}$ (THP-1 cells; (B)). C and D: Cells were incubated in medium alone (control) or LPS (10 ng/ml for A549 cells (C) or $1 \mathrm{ng} / \mathrm{ml}$ for THP-1 cells (D)) in the presence or absence of CAM, TEL, GRNX and ABPC $(1$ or $10 \mu \mathrm{g} / \mathrm{ml})$. The concentrations of IL-8 in the culture supernatants were measured by ELISA. Every experiment was performed in duplicate, and the values represent means \pm S.E.M. of four independent experiments. \# denotes a statistically significant difference as compared with control $(\mathrm{P}<0.05)$, and $*$ denotes a statistically significant difference as compared with LPS stimulation alone. $(\mathrm{P}<0.05)$ 
(A)

$\begin{array}{cccccc}\text { LPS } & 0 & 10 & 100 & 1 & 10 \\ & & \mathrm{ng} / \mathrm{ml} & \mathrm{ng} / \mathrm{ml} & \mu \mathrm{g} / \mathrm{ml} & \mu \mathrm{g} / \mathrm{ml} \\ \text { p-ERK } & & & & & \end{array}$

(C)

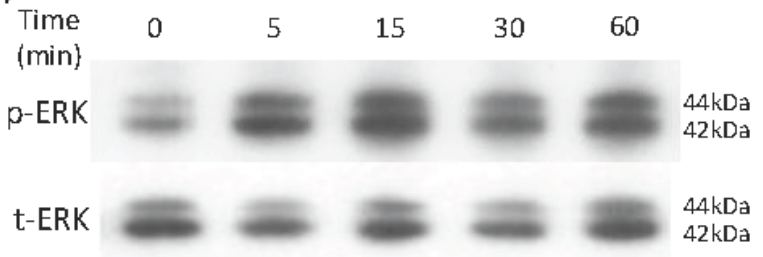

(E)

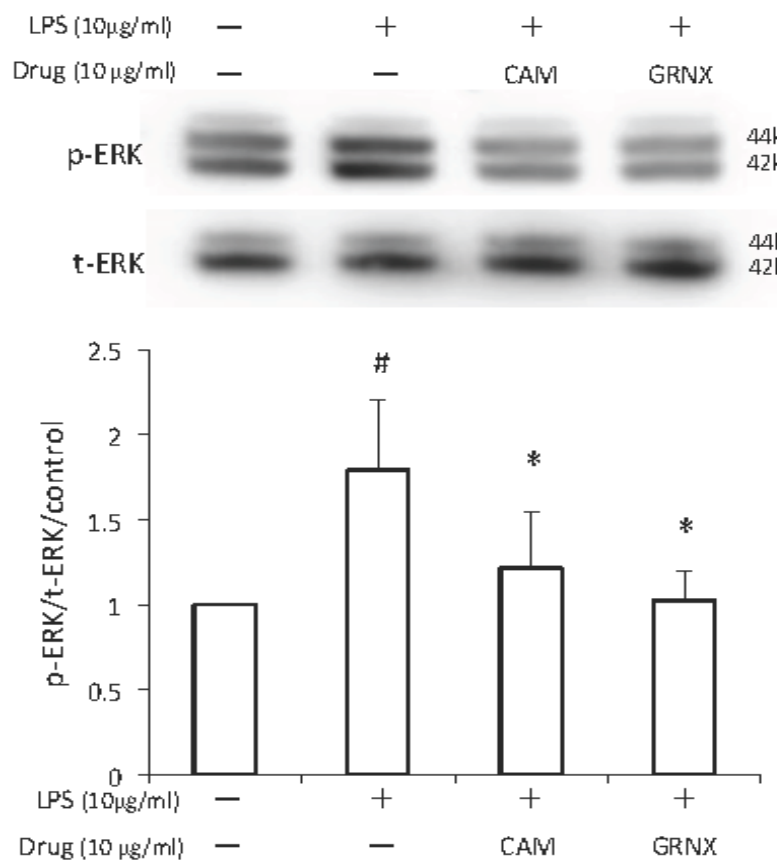

(B)

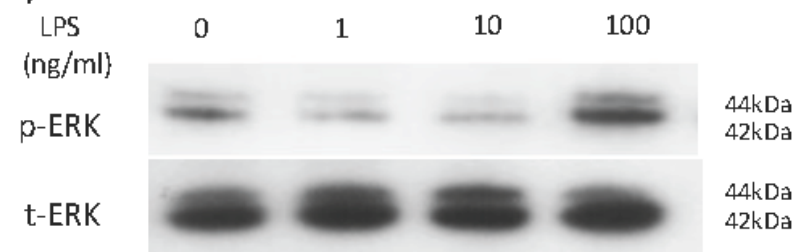

(D)

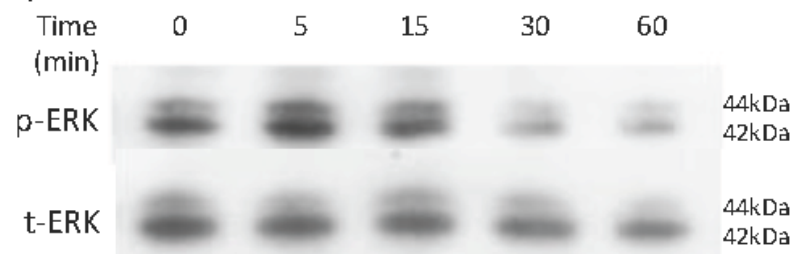

$(\mathrm{F})$

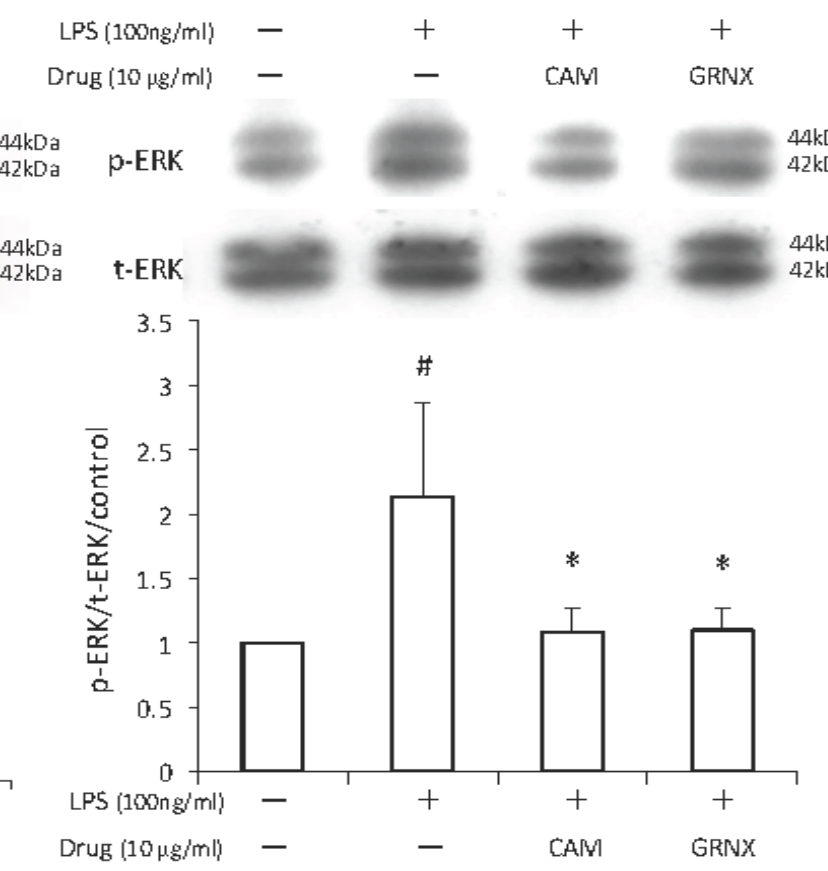

Fig. 3. Effect of clarithromycin (CAM) and garenoxacin (GRNX) on the phosphorylated ERK (p-ERK)1/2 A and B: Concentration-dependent studies. A549 (A) and THP-1 cells (B) were stimulated with the indicated concentration of LPS for 5 min. C and D: Time-dependent studies. Cells were stimulated with $10 \mu \mathrm{g} / \mathrm{ml}$ of LPS (A549; (C)) or $100 \mathrm{ng} / \mathrm{ml}$ of LPS (THP-1; (D)) for the indicated amounts of time. $\mathbf{E}$ and F: Cells were preincubated with $10 \mu \mathrm{g} / \mathrm{ml}$ of CAM or GRNX for $3 \mathrm{~h}$ and then stimulated with $10 \mu \mathrm{g} / \mathrm{ml}$ of LPS for $15 \mathrm{~min}$ (A549; (E)) or $100 \mathrm{ng} / \mathrm{ml}$ of LPS for $5 \mathrm{~min}$ (THP-1; (F)) before performing western blot analysis. The ratio of p-ERK to total-ERK was calculated for each sample. Every experiment was performed in duplicate, and the values are the means \pm S.E.M. of four independent experiments. \# denotes a statistically 
significant difference as compared with control $(\mathrm{P}<0.05)$, and $*$ denotes a statistically significant difference compared with the results for the LPS-stimulated cells without antibiotic $(\mathrm{P}<0.05)$. 


\section{Table 1. Inhibitory effects of antibiotic on IL-8 production induced by stimuli in}

vitro. Inhibitory ratios of control stimulator exposure are quoted from the text of references or measured from the graphs provided in each reference. In the case that several cytokines were measured, results of only IL-8 measurement are shown in this table. Underlined numbers denote a statistically significant concentration.

Abbreviations: hPBMC, human peripheral blood mononuclear cell; NHBE, normal human bronchial epithelial cell; EM, erythromycin; CAM, clarithromycin; AZM, azithromycin; TEL, telithromycin; JM, josamycin; CEZ, cefazolin; GRNX, garenoxacin; MFLX, moxifloxacin; CPFX, ciprofloxacin; GFLX, gatifloxacin.

\begin{tabular}{|c|c|c|c|c|c|}
\hline cells & stimulus & compound & $\begin{array}{l}\text { incubation } \\
\text { time (h) }\end{array}$ & $\begin{array}{c}\text { exposure } \\
\text { concentration }\end{array}$ & reference \\
\hline THP-1 & LPS & MFLX & 24 & 1. $10, \underline{30} \mu \mathrm{g} / \mathrm{mn} 1$ & (Zhang and Ward, 2008) \\
\hline THP-1 & LPS & besifloxacin & 24 & $1,10, \underline{30} \mu \mathrm{g} / \mathrm{ml}$ & (Zhang and Ward, 2008) \\
\hline THP-1 & Aspergillus fumigatus & MFLX & 8 & $\underline{5}, \underline{10}, \underline{20} \mu \mathrm{g} / \mathrm{ml} 1$ & (Shalit et al., 2006) \\
\hline hPBMC & LPS & MFLX & 4 & $\underline{5}, \underline{10}, \underline{20} \mu \mathrm{g} / \mathrm{ml} 1$ & (Weiss et al., 2004) \\
\hline THP-1 & LPS & MFLX & 24 & $\underline{5}, \underline{10}, \underline{20} \mu \mathrm{g} / \mathrm{ml} 1$ & (Weiss et al., 2004) \\
\hline THP-1 & LPS & CAM & 6 & $\underline{1}, \underline{10} \mu \mathrm{g} / \mathrm{ml}$ & (Kikuchi et al., 2002) \\
\hline hPBMC & LPS & CAM & 6 & $\underline{0.1}, \underline{1}, \underline{10} \mu \mathrm{g} / \mathrm{ml}$ & (Kikuchi et al., 2002) \\
\hline A549 & LPS & MFLX & 24 & $\underline{10} \mu \mathrm{g} / \mathrm{ml}$ & (Donnarumma et al., 2007) \\
\hline NHBE & P. aenuginosa flagellin & $\mathrm{CAM}$ & 4 & $10 \mu \mathrm{g} / \mathrm{ml}$ & (Shinkai et al., 2007) \\
\hline NHBE & P. aenuginosa flagellin & $\mathrm{CAM}$ & 9 & $\underline{10} \mu \mathrm{g} / \mathrm{ml}$ & (Shinkai et al., 2007) \\
\hline NHBE & P. aenuginosa flagellin & CAM & 18 & $10 \mu \mathrm{g} / \mathrm{ml}$ & (Shinkai et al., 2007) \\
\hline NHBE & P. aenuginosa flagellin & CAM & 24 & $10 \mu \mathrm{g} / \mathrm{ml}$ & (Shinkai et al., 2007) \\
\hline IB3 (CF cell line) & TNF-alpha & MFLX & 48 & $5, \underline{10}, \underline{20}, \underline{50} \mu \mathrm{g} / \mathrm{ml}$ & (Blau et al., 2007) \\
\hline IB3 & TNF-alpha & CPFX & 48 & $5,10,20, \underline{50} \mu \mathrm{g} / \mathrm{ml}$ & (Blau et al., 2007) \\
\hline C38 (CF cell line) & TNF-alpha & MFLX & 48 & $5, \underline{10}, \underline{20}, \underline{50} \mu \mathrm{g} / \mathrm{ml}$ & (Blau et al., 2007) \\
\hline C38 & TNF-alpha & CPFX & 48 & $5,10,20, \underline{50} \mu \mathrm{g} / \mathrm{ml}$ & (Blau et al., 2007) \\
\hline IB3 and C38 & TNF-alpha & $\mathrm{AZM}$ & 48 & $5,10,20,50 \mu \mathrm{g} / \mathrm{ml}$ & (Blau et al., 2007) \\
\hline IB3 and C38 & IL-1beta & MFLX, CPFX, AZM & 48 & $5,10,20,50 \mu \mathrm{g} / \mathrm{ml}$ & (Blau et al., 2007) \\
\hline hPBMC & Stx2 (Shiga toxitl) & TEL & 18 & $\underline{2.5}, \underline{5}, \underline{10} \mu \mathrm{g} / \mathrm{ml} \mathrm{l}$ & (Nakagawa et al., 2003) \\
\hline hPBMC & Stx2 (Shiga toxin) & EM & 18 & $2.5,5,10 \mu \mathrm{g} / \mathrm{ml}$ & (Nakagawa et al., 2003) \\
\hline hPBMC & Stx2 (Shiga toxitı) & $\mathrm{CAM}$ & 18 & $2.5,5,10 \mu \mathrm{g} / \mathrm{ml}$ & (Nakagawa et al., 2003) \\
\hline hPBMC & Stx2 (Shiga toxin) & $\mathrm{AZM}$ & 18 & $\underline{2.5}, \underline{5}, \underline{10} \mu \mathrm{g} / \mathrm{ml}$ & (Nakagawa et al., 2003) \\
\hline $\mathrm{hPBMC}$ & LPS & $\mathrm{TEL}_{2} \mathrm{EM}_{2} \mathrm{CAM}, \mathrm{AZM}$ & 18 & $2.5,5,10 \mu \mathrm{g} / \mathrm{ml} l$ & (Nakagawa et al., 2003) \\
\hline $\mathrm{BEAS}-2 \mathrm{~B}$ & IL-1alpha & EM & 24 & $\underline{1}, \underline{10} \mu \mathrm{M}$ & (Takizawa et al., 1997) \\
\hline BEAS-2B & IL-lalpha & CAM & 24 & $\underline{1}, \underline{10} \mu \mathrm{M}$ & (Takizawa et al., 1997) \\
\hline $\mathrm{BEAS}-2 \mathrm{~B}$ & IL-lalpha & $\mathrm{CEZ}, \mathrm{TC}, \mathrm{JM}$ & 24 & $1,10 \mu \mathrm{M}$ & (Takizawa et al., 1997) \\
\hline THP-1 & LPS/PMA & radicicol & $6,12,24$ & $200 \mathrm{ng} / \mathrm{ml}$ & (Na et al., 2001) \\
\hline A549 & LPS & $\mathrm{CAM}$ & 24 & $\underline{1}, \underline{10} \mu \mathrm{g} / \mathrm{ml}$ & our study \\
\hline A549 & LPS & TEL & 24 & $\underline{1}, \underline{10} \mu \mathrm{g} / \mathrm{ml}$ & our study \\
\hline A549 & LPS & GRNX & 24 & $1, \underline{10} \mu \mathrm{g} / \mathrm{ml}$ & our study \\
\hline THP-1 & LPS & $\mathrm{CAM}$ & 9 & $1,10 \mu \mathrm{g} / \mathrm{ml}$ & our study \\
\hline THP-1 & LPS & TEL & 9 & $1,10 \mu \mathrm{g} / \mathrm{ml}$ & our study \\
\hline THP-1 & LPS & GRNX & 9 & $1, \underline{10} \mu \mathrm{g} / \mathrm{ml}$ & our study \\
\hline
\end{tabular}

